\title{
CHARACTERISATION OF CONSERVATIVE LIQUIDS BASED ON LIQUID RUBBER, THE SALTS OF THE NATURAL PETROLEUM ACIDS AND NITRO COMPOUNDS- $\mathrm{C}_{14} \mathrm{H}_{28}$
}

\author{
Yegana AGHAZADA, Vaqif ABBASOV, Senan ABDULLAYEV, Elgun HASANOV, \\ Ulviya YOLCHUYEVA
}

Institute of Petrochemical Processes named after acad. Yu.G. Mamedaliyev, Azerbaijan National Academy of Sciences, AZ1025, Azerbaijan, Baku,. Khojali ave., 30

In this proceeding, the compositions of the T-30 turbine oil with liquid rubber, $\mathrm{Co}, \mathrm{Ni}, \mathrm{Zn}, \mathrm{Mg}$ and $\mathrm{Ba}$ salts of the natural petroleum acids (NPA) boiling in the range $220-340^{\circ} \mathrm{C}$ and nitro compounds which are produced on the basis of $\mathrm{C}_{14} \mathrm{H}_{28} \alpha$-olefins have been investigated in different ratio and contents as conservative liquids. The physical and chemical properties of the produced compositions have been studied and the morphology of inhibited carbon steel surface was analyzed and characterized by Fourier transform-infrared (FT-IR). Effect of temperature on
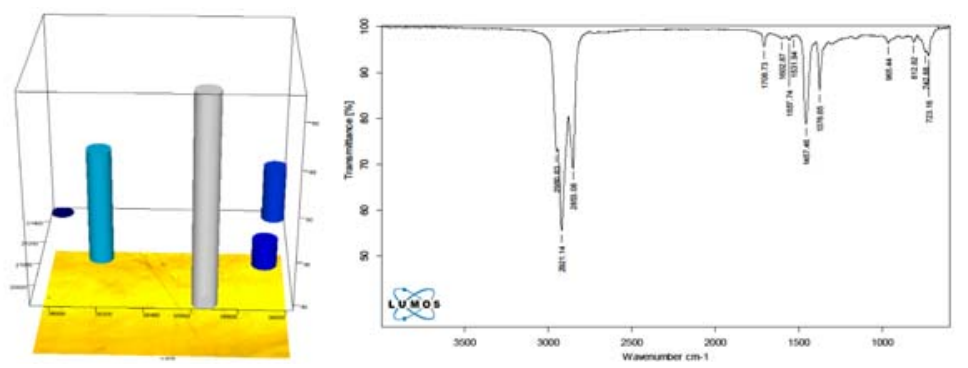

inhibition efficiency and thermodynamic parameters have also been reported. STA-449 F3- thermal analyzer was used for the thermogravimetric analysis (TG/DTA) of the prepared conservative liquids. The researches have been operated with different concentrations of inhibitor on the steel plates in condensation and environment phases in the experiment chamber called «corrosionbox».

\section{INTRODUCTION}

Corrosion is a fundamental process playing an important role in economics and safety, particularly for metals. The use of inhibitors is one of the most practical methods for protection against corrosion, especially in acidic media. Carbon steel is an alloy of iron, widely used in petrochemical and metallurgical industries. Also, used as construction material owing to its excellent mechanical properties and cost effectiveness. However, it easily undergoes corrosion in various environmental conditions ${ }^{1-3}$. Acid solutions are widely used in industry, the most important fields of application being acid pickling, industrial acid cleaning, acid decaling and oil well acidizing. Because of the general aggressivity of acid solutions, inhibitors are commonly used to reduce the corrosive attack on metallic materials. Most of the well-known acid inhibitors are organic compounds containing $\mathrm{N}$, $\mathrm{O}, \mathrm{P}, \mathrm{S}$ and aromatic rings or triple bonds. It was reported before that, the protection efficiency varies in the order: $\mathrm{O}<\mathrm{N}<\mathrm{S}<\mathrm{P}^{4-6}$. In general, organic compounds are effective inhibitors of aqueous corrosion of many metals and alloys. The use of chemical inhibitors to decrease the rate of corrosion processes of carbon steel is quite varied. Former studies concluded that the adsorption on the mild steel surface depends mainly on the physicochemical

\footnotetext{
${ }^{*}$ Corresponding author: yeqana.aqazade@mail.ru
} 
properties of the inhibitor group such as the planarity of the system, the presence of multiple adsorption active centres with alone pair and, or $\pi$ orbitals, the electronic density of the donor atom and the molecular size. Therefore, the choice of effective inhibitors is based on their structure, mechanism of action and electron donating ability. Conservative liquids are widely used in order to build up a corrosion protection system for metal containing complex technological appliances ${ }^{7-10}$. The widespread investigation of the inhibitors in the conservative liquids is based on its economic efficiency and simple structure of application technology. As a result of its chemisorption ability, inhibitor in the conservative liquid decreases the dissolution by pacifying the processes on the surface, provides a protective coating by creating a complex in the sphere of influence and prevents the corrosion of metal. In recent years, the application of the composition based reagents as corrosion inhibitors are actual ${ }^{11-13}$.

In the given proceeding, the solution of the composition of inhibitor that is obtained by complex of the $\mathrm{Co}, \mathrm{Ni}, \mathrm{Zn}, \mathrm{Mg}$ va Ba metal salts of the natural petroleum acids with nitro compounds and liquid rubber in T-30 oil has been applied as a corrosion protector. The compounds those have inhibitor properties in the prepared conservative liquids mainly consist of 3 components: metal salts of natural petroleum acid, aliphatic based nitro compunds and liquid rubber.

\section{EXPERIMENTAL}

The metal (Co, Ni, Zn, Mg, Ba) salts of technical petroleum acids which are separated from Azerbaijan kerosene and diesel fractions and is soluble in organic solvents have been synthesized by the general methods. The NPA which is used in the process has been obtained by the dearomatization of the diesel fraction with the boiling range of $220-340^{\circ} \mathrm{C}$. The dearomatization process has been operated with the extraction method. N-methyl pyrrolidone has been used as an extraction solvent. The physical and chemical properties of the fraction which is obtained from the extraction process were like this: $\rho=0,8294 \mathrm{~g} / \mathrm{cm}^{3} ; \mathrm{n}=1,4677 ; \mathrm{M}_{\mathrm{B}}=187$; freezing point $=-51^{\circ} \mathrm{C}$; boiling point $=220-340^{\circ} \mathrm{C}$, kinematic viscosity at $20^{\circ} \mathrm{C} \sim 5.52$ $\mathrm{mm}^{2} / \mathrm{sec}$, total sulfur content $\sim 0,03 \%$, the amount of aromatic hydrocarbos $\sim 1 \%$ (by mass).

The composition of the solution which contains synthesized the metal salts of the NPA and nitro compound with the polybutadiene based liquid rubber has been prepared and tested on steel plates. The liquid rubber which is used in the process has been synthesized on the basis of stereo regular structured 1,4 cis - polybutadiene (low molecular weight, $\mathrm{M}_{\mathrm{r}}$ 1800-3000), which has a wide range of industrial application microstructure: 1,4 cis-75 80\% ; 1,4 trans-18 22\% ; 1,2units-2 7\%, number of units $\sim 80$ ). The cis- position of the methyl groups in liquid rubber facilitates the adsorption on the metal surface ${ }^{14-15}$. Nitro compound is synthesized by using treating $\mathrm{C}_{14} \mathrm{H}_{28}$ which is produced by the oligomerization of ethylene with nitro compound with nitric acid in optimum condition (sodium nitrite is used as an inisiator). The amount of the active components was 1:1:1 (in grams). "T-30" turbine oil has been used as a solvent.

The physical and chemical properties of the composition of inhibitor have been investigated and its content has been proved by IR spectrosopy method ${ }^{16-18}$.

\section{Name of the samples}

1. $\mathrm{T}-30$ oil $+\mathrm{Zn}$ salt of the NPA + liquid rubber $-10 \%$

2. $\mathrm{T}-30$ oil + Co salt of the NPA + liquid rubber $-10 \%$

3. T- 30 oil + Ni salt of the NPA + liquid rubber- $10 \%$

4. T-30 oil $+\mathrm{Ni}$ salt of the NPA+ Nitro compound+liquid rubber- $10 \%$

5. T-30 oil + Co salt of the NPA+ Nitro compound + liquid rubber- $10 \%$

In order to determine the identity of the conservation liquid, 5 different points have been chosen on given sample and IR spectra have been evaluated ${ }^{19-20}$. The following wavelength has been obtained by the spectral analysis of the conservation content of the inhibitor (Co salt of NPA + Nitro compound + liquid rubber) which shows the maximum efficiency:

The content of the composition has been tested by IRFurye LUMOS (BRUKER) microscope in the range of 600$4000 \mathrm{~cm}^{-1}$ wavelength. The deformation $\left(1376,1457 \mathrm{~cm}^{-1}\right)$ and valence $\left(2921,2950 \mathrm{~cm}^{-1}\right)$ oscilations of structure groups $\left(\mathrm{CH}_{3}\right.$ and $\left.\mathrm{CH}_{2}\right)$ which belong to NPA are observed in the spectrum of the approved sample. At the same time, the resonance signals for $\mathrm{C}-\mathrm{H}$ bond and valence oscillations for $\mathrm{C}-\mathrm{NO}_{2}$ group are seen at $723 \mathrm{~cm}^{-1}$ and $1558 \mathrm{~cm}^{-1}$ wavelength, respectively. The comparison of the IR spectrum of all 5 points on the sample shows that they are practically the same which proves that the conservation materials are distributed on the metal surface homogeneously.

Table 1

Main physical properties of conservation liquids

\begin{tabular}{|c|c|c|c|c|c|c|c|}
\hline \multirow[t]{2}{*}{ Name of the property } & \multirow{2}{*}{$\begin{array}{c}\text { Name of the } \\
\text { device }\end{array}$} & \multirow[t]{2}{*}{ ASTM } & \multicolumn{5}{|c|}{ Samples } \\
\hline & & & 1 & 2 & 3 & 4 & 5 \\
\hline Freezing point ${ }^{\circ} \mathrm{C}$ & Stanhope Seta & $\begin{array}{l}\text { ASTM } \\
\text { D2386 }\end{array}$ & -35 & -25 & -25 & -30 & -25 \\
\hline Viscosity $\mathrm{mm}^{2} / \mathrm{s},{ }^{\circ} \mathrm{C} 40$ & TW4000 & $\begin{array}{l}\text { ASTM } \\
\text { D445 }\end{array}$ & 60.88 & 66.93 & 61.96 & 56.47 & 53.99 \\
\hline $\begin{array}{c}\text { Viscosity, } \mathrm{mm}^{2} / \mathrm{s},{ }^{\circ} \mathrm{C} \\
100\end{array}$ & TW4000 & $\begin{array}{l}\text { ASTM } \\
\text { D445 }\end{array}$ & 8.31 & 26.75 & 8.72 & 7.98 & 7.63 \\
\hline Density, $\mathrm{g} / \mathrm{cm}^{3}$ & DMA $4500 \mathrm{M}$ & D5002 & 0.9072 & 0.9112 & 0.9136 & 0.9093 & 0.9090 \\
\hline
\end{tabular}




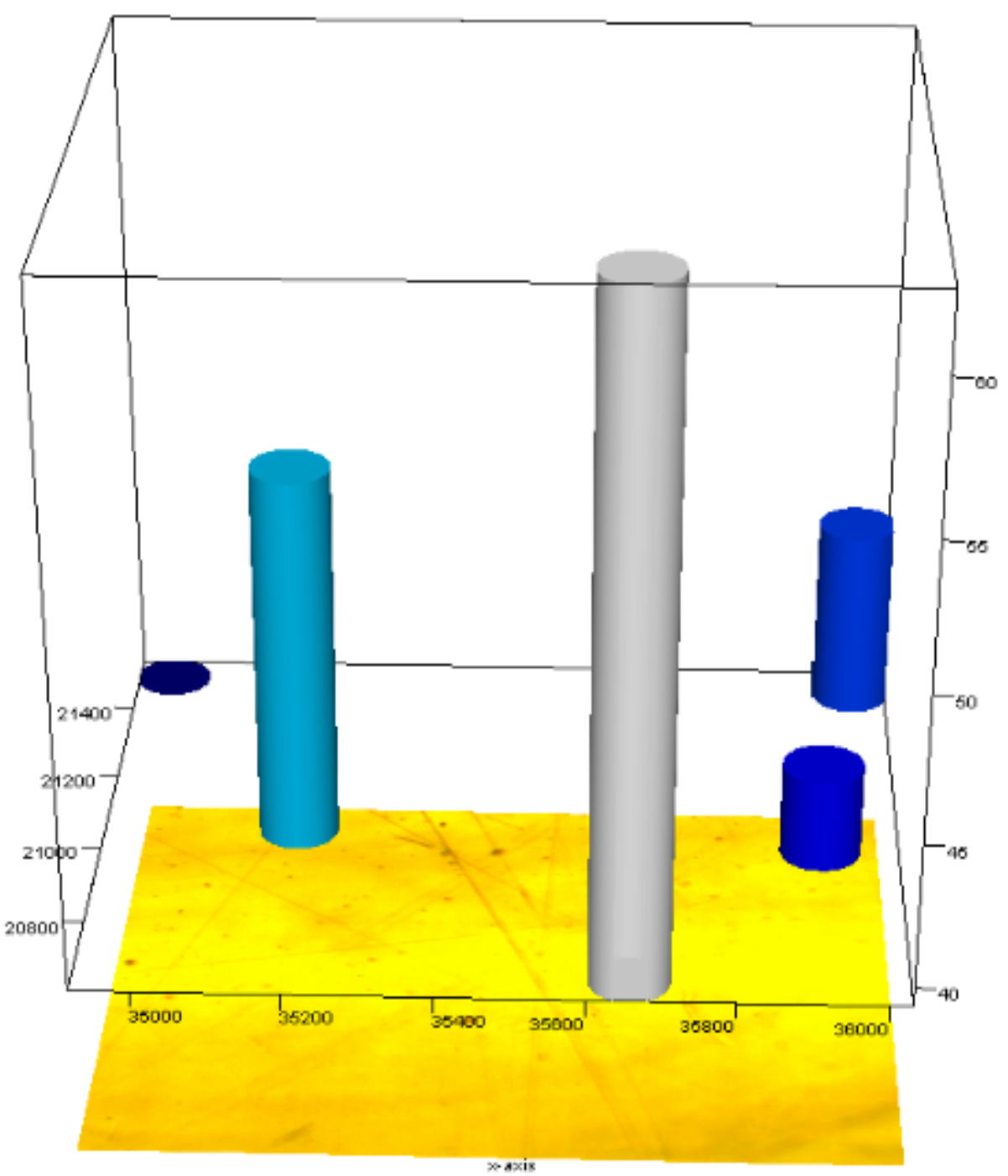

Fig. 1 -The microscopic view of 5 selected points in the sample. Fig.1.2 IR spectra of the $1^{\text {st }}$ point.

Table 2

Change in the mass loss

\begin{tabular}{c|c|c}
\hline Tempera-ture ${ }^{\circ} \mathrm{C}$ & Mass loss, mg & Mass loss, $\%$ \\
\hline 120 & 0 & - \\
140 & 0.2 & 1.48 \\
160 & 0.4 & 2.96 \\
180 & 0.6 & 4.44 \\
200 & 1.0 & 7.41 \\
220 & 1.4 & 10.37 \\
240 & 2.6 & 19.25 \\
260 & 4.0 & 29.26 \\
280 & 6.0 & 44.44 \\
300 & 8.6 & 63.70 \\
320 & 11.0 & 81.48 \\
340 & 11.4 & 84.44 \\
360 & 11.4 & 84.44 \\
380 & 11.6 & 85.92 \\
400 & 11.8 & 87.64 \\
420 & 12.0 & 88.88 \\
440 & 12.0 & 88.88 \\
460 & 12.2 & 90.37 \\
\hline
\end{tabular}


STA-449 F3, NETZSCH thermal analyzer was used for the thermogravimetric analysis (TG/DTA - change in mass depending on the temperature and differential thermal analysis) of the prepared conservative liquids (Fig.2). The processes has been operated by using nitrogen gas flow and by increasing the temperature by $20^{\circ} \mathrm{C}$ per minute. The evaluation of thermal analysis of the Sample 5 (Table 1) shows that there is no chemical change in the STA (Simultaneous Thermal Analysis) curve, the peak at $360^{\circ} \mathrm{C}$ coincides with the complete disintegration of the compozition. The curve for the mass loss is observed in the TG (Thermogravimetry) curve which proves the homogeneity of the composition ${ }^{21-22}$. The dependence of the change in the mass loss on the temperature is given in the Table 2 .
The specific contact method has been used in order to determine the resistivity (specific conductance) of the compositions. The measurement process has been operated by the E6-13A teraohmmeter. The measurement places are cleaned with alcohol before each process and the distance between electrodes is determined. Then, the substance is poured until the area between electrodes is filled and the resistivity is measured. The resistivity is calculated according to $\rho=\pi \mathrm{r}^{2} / \mathrm{d}$ equation and the conductance is determined with the following equation: $\sigma=1 / \rho$. The physical components in the formulae are following: $\rho$-resistance, $\pi$-constant, $\sigma$ conductance, r-radius of the measurement electrode, ddistance between electrodes. The determined electrical conductivity values of the samples are shown in the Table 3 .

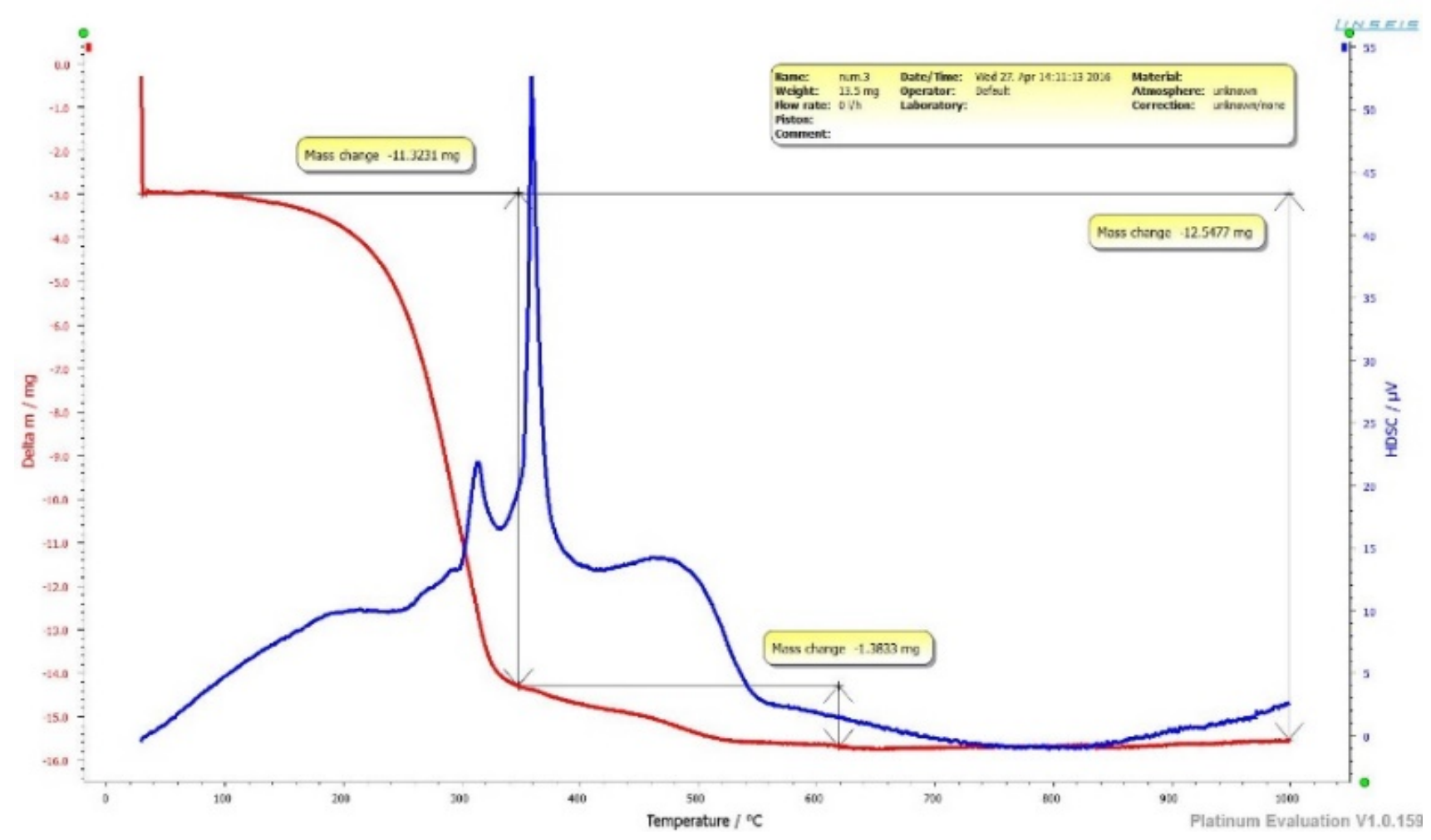

Fig. 2 - TG/DTA curves of the sample 5.

Table 3

Change in the electrical conductivity due to temperature

\begin{tabular}{|c|c|c|c|c|c|c|c|c|c|}
\hline № & $\begin{array}{l}\text { Tempe- } \\
\text { rature, } \\
\mathrm{K}\end{array}$ & $\begin{array}{l}\text { Special } \\
\text { resistance } \\
\rho, \mathrm{Om} \cdot \mathrm{m}\end{array}$ & $\begin{array}{l}\text { Electrical } \\
\text { conductivity } \\
\sigma, \mathrm{S} / \mathrm{sm}\end{array}$ & № & $\begin{array}{l}\text { Special } \\
\text { resistan. } \\
\rho, \mathrm{Om} \cdot \mathrm{m}\end{array}$ & $\begin{array}{l}\text { Electr. } \\
\text { cond. } \\
\sigma, \mathrm{S} / \mathrm{sm}\end{array}$ & № & $\begin{array}{l}\text { Special } \\
\text { resistan. } \\
\rho, \text { Om } \cdot \mathrm{m}\end{array}$ & $\begin{array}{l}\text { Electr. } \\
\text { cond. } \\
\sigma, \mathrm{S} / \mathrm{sm}\end{array}$ \\
\hline \multirow[t]{13}{*}{1} & 298 & $6,9 \cdot 10^{8}$ & $1,4 \cdot 10^{-11}$ & 2 & $8,4 \cdot 10^{8}$ & $1,1 \cdot 10^{-11}$ & 3 & $1,08 \cdot 10^{10}$ & $9,2 \cdot 10^{-13}$ \\
\hline & 303 & $6 \cdot 10^{8}$ & $1,6 \cdot 10^{-11}$ & & $7,9 \cdot 10^{8}$ & $1,3 \cdot 10^{-11}$ & & $1,04 \cdot 10^{10}$ & $9,6 \cdot 10^{-13}$ \\
\hline & 308 & $6 \cdot 10^{8}$ & $1,6 \cdot 10^{-11}$ & & $7,4 \cdot 10^{8}$ & $1,4 \cdot 10^{-11}$ & & $1,04 \cdot 10^{10}$ & $9,6 \cdot 10^{-13}$ \\
\hline & 313 & $5,6 \cdot 10^{8}$ & $1,7 \cdot 10^{-11}$ & & $6,9 \cdot 10^{8}$ & $1,4 \cdot 10^{-11}$ & & $1 \cdot 10^{10}$ & $1 \cdot 10^{-12}$ \\
\hline & 318 & $5,6 \cdot 10^{8}$ & $1,7 \cdot 10^{-11}$ & & $6,5 \cdot 10^{8}$ & $1,5 \cdot 10^{-11}$ & & $9,2 \cdot 10^{9}$ & $1,1 \cdot 10^{-12}$ \\
\hline & 323 & $5,2 \cdot 10^{8}$ & $1,9 \cdot 10^{-11}$ & & $6,1 \cdot 10^{8}$ & $1,6 \cdot 10^{-11}$ & & $8 \cdot 10^{9}$ & $1,3 \cdot 10^{-12}$ \\
\hline & 328 & $5,2 \cdot 10^{8}$ & $1,9 \cdot 10^{-11}$ & & $5,9 \cdot 10^{8}$ & $1,7 \cdot 10^{-11}$ & & $6,8 \cdot 10^{9}$ & $1,5 \cdot 10^{-12}$ \\
\hline & 333 & $4,8 \cdot 10^{8}$ & $2,1 \cdot 10^{-11}$ & & $5,7 \cdot 10^{8}$ & $1,8 \cdot 10^{-11}$ & & $6 \cdot 10^{9}$ & $1,7 \cdot 10^{-12}$ \\
\hline & 338 & $4,6 \cdot 10^{8}$ & $2,2 \cdot 10^{-11}$ & & $5,3 \cdot 10^{8}$ & $1,9 \cdot 10^{-11}$ & & $5 \cdot 10^{9}$ & $2 \cdot 10^{-12}$ \\
\hline & 343 & $4,2 \cdot 10^{8}$ & $2,4 \cdot 10^{-11}$ & & $4,9 \cdot 10^{8}$ & $2 \cdot 10^{-11}$ & & $4 \cdot 10^{9}$ & $2,5 \cdot 10^{-12}$ \\
\hline & 348 & $3,8 \cdot 10^{8}$ & $2,6 \cdot 10^{-11}$ & & $4,6 \cdot 10^{8}$ & $2,2 \cdot 10^{-11}$ & & $3,6 \cdot 10^{9}$ & $2,8 \cdot 10^{-12}$ \\
\hline & 353 & $3,8 \cdot 10^{8}$ & $2,6 \cdot 10^{-11}$ & & $4,1 \cdot 10^{8}$ & $2,4 \cdot 10^{-11}$ & & $3,2 \cdot 10^{9}$ & $3,1 \cdot 10^{-12}$ \\
\hline & 358 & $3,2 \cdot 10^{8}$ & $3,1 \cdot 10^{-11}$ & & $3,8 \cdot 10^{8}$ & $2,6 \cdot 10^{-11}$ & & $2,8 \cdot 10^{9}$ & $1,3 \cdot 10^{-12}$ \\
\hline
\end{tabular}




\section{Name of the samples}

1. T-30 oil + Co salt of the NPA+ Nitro compound+ liquid rubber

2. T-30 oil $+\mathrm{Ni}$ salt of the NPA+ Nitro compound + liquid rubber

\section{3. $\mathrm{T}-30$ oil + liquid rubber}

The graph showing the change of the electrical conductivity of the conservative liquids due to temperature is given below:

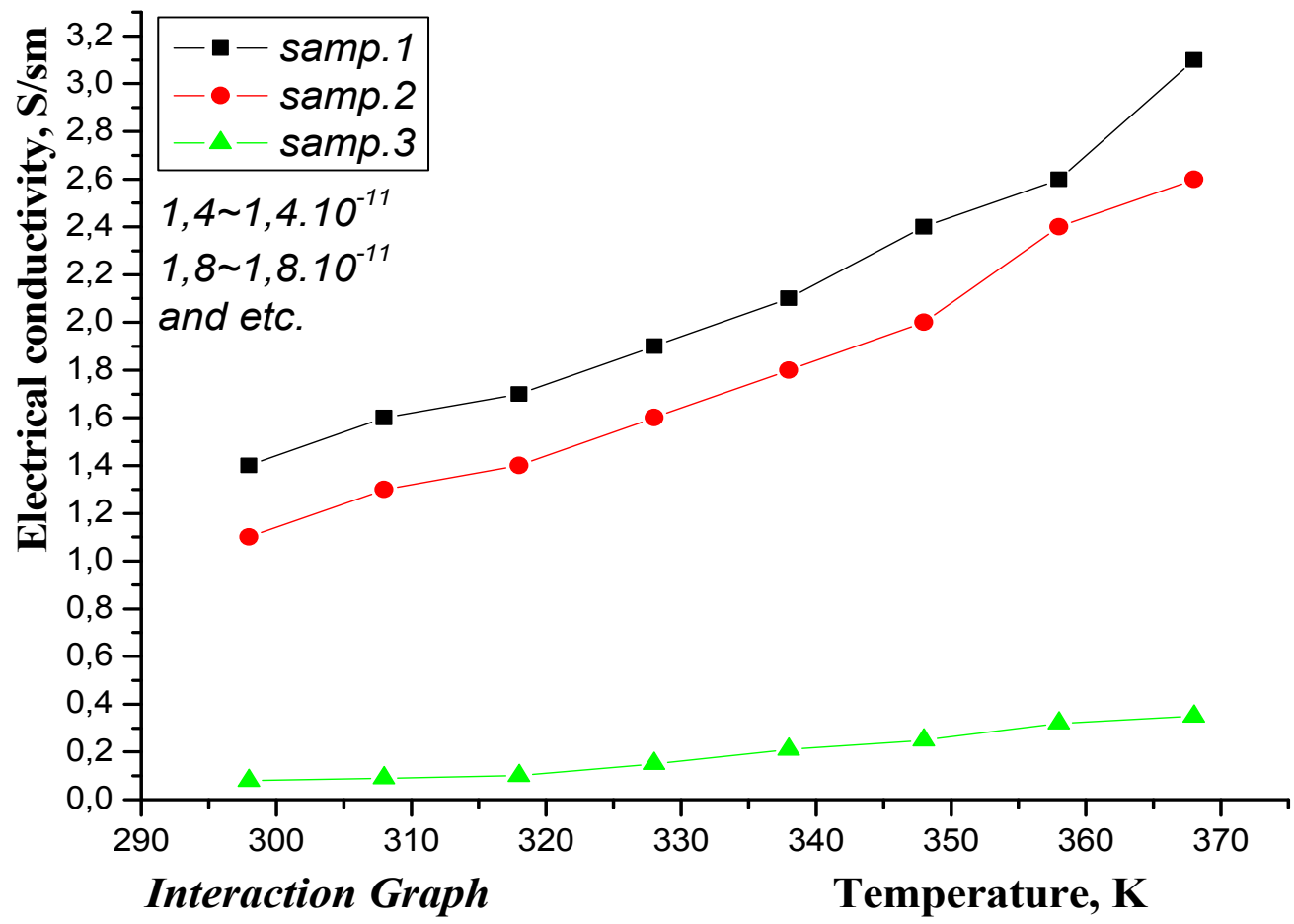

Fig. 3 - The graph of electrical conductivity against temperature.

Obtained composition has been tested as conservative liquid on steel plates by dissolving T-30 oil (7\% and $10 \%)$. The experiments were carried out with DC01 (CR4) carbon steel specimens. The mainly chemical composition (wt $\%)$ of the carbon steel was listed as follows: $\mathrm{C} \% \sim 0.07$; $\mathrm{Si} \% \sim 0,01$; $\mathrm{Mn} \% \sim 0.2-0.35 ; \mathrm{Ni} \% \sim 0.06 ; \mathrm{S} \% \sim 0.025 ; \mathrm{P} \% \sim 0.02 ; \mathrm{Cr} \% \sim 0.03$; $\mathrm{Al} \% \sim 0.02-0.07 ; \mathrm{Cu} \% \sim 0.06$; Fe balance. The test sample size was $150 \times 100 \times 1 \mathrm{~mm}$. The carbon steel plates were prepared, degreased and cleaned with deionized water and alcohol. The experiment has been operated according to the current standards in the chamber called "corrosionbox" which is considered as a modern technological device. The process has been carried out in two phases: condensation and atmospheric phase. Electronic appliances have been used in order to adjust the standard parameters for obtaining sustainable trials in the experiment chamber. For the condensation phase, these parameters are the temperature of the chamber and the duration of the trial, for the environmental phase, these are the temperature of the moisturizing agent and the chamber and the duration of the trial. The duration of the trial was in the interval of 1 minute - 9999 hours and the temperature of the chamber was $20-50^{\circ} \mathrm{C}$ for the condensation phase, whereas the temperature of the moisturizing agent was $20-80^{\circ} \mathrm{C}$ and the remaining parameters were the same for the environmental phase.

\section{RESULTS AND DISCUSSION}

As can be clearly seen from the table (Table 4), metal sheets were protected 31 and 75 days by using T-30 turbine oil and liquid rubber respectively, however, these pointers were higher when inhibitor was used. When $7 \%$ concentration of the inhibitor (Co salt of NPA + Nitro compound + Liquid rubber) was used, in the condensation phase, the protection of the metal sheets from the corrosion lasted 301 days, however, in environmental phase, it was 384 days. In 10\% concentration, it was 322 and 401 days, respectively. At the same time, the corrosion protection efficiency of the conservative liquids those have been produced on the basis of the complex of the metal salts of NPA with nitro compounds was high in comparison to current demand. 
Table 4

The results of the trials of synthesized salts as conservation liquids both individually and as compositions

\begin{tabular}{|c|c|c|c|c|c|}
\hline \multirow{3}{*}{ № } & \multicolumn{3}{|c|}{ The solutions of the compositions in the "T-30" oil } & \multicolumn{2}{|c|}{$\begin{array}{c}\text { The duration } \\
\text { of corrosion protection, days }\end{array}$} \\
\hline & \multirow[t]{2}{*}{ Content } & \multicolumn{2}{|c|}{$\begin{array}{l}\text { The amount of the } \\
\text { components }(\%)\end{array}$} & \multirow[t]{2}{*}{ Condensation phase } & \multirow[t]{2}{*}{$\begin{array}{c}\text { Atmospheric } \\
\text { phase }\end{array}$} \\
\hline & & Inhibitor & Solution & & \\
\hline 1 & T-30 oil+ Liquid rubber & - & - & 31 & 75 \\
\hline 2 & $\begin{array}{l}\text { Ni salt of the NPA } \\
\text { Liquid rubber }\end{array}$ & $\begin{array}{l}5 \\
5\end{array}$ & 10 & 95 & 197 \\
\hline 3 & $\begin{array}{l}\text { Ni salt of the NPA } \\
\text { Nitro compound } \\
\text { Liquid rubber }\end{array}$ & $\begin{array}{l}3,33 \\
3,33 \\
3,34 \\
\end{array}$ & 7 & 267 & 311 \\
\hline 4 & $\begin{array}{l}\text { Ni salt of the NPA } \\
\text { Nitro compound } \\
\text { Liquid rubber }\end{array}$ & $\begin{array}{l}3,33 \\
3,33 \\
3,34 \\
\end{array}$ & 10 & 291 & 350 \\
\hline 5 & $\begin{array}{l}\text { Co salt of the NPA } \\
\text { Liquid rubber }\end{array}$ & $\begin{array}{l}5 \\
5 \\
\end{array}$ & 10 & 138 & 219 \\
\hline 6 & $\begin{array}{l}\text { Co salt of the NPA } \\
\text { Nitro compound } \\
\text { Liquid rubber }\end{array}$ & $\begin{array}{l}3,33 \\
3,33 \\
3,34 \\
\end{array}$ & 7 & 301 & 384 \\
\hline 7 & $\begin{array}{l}\text { Co salt of the NPA } \\
\text { Nitro compound } \\
\text { Liquid rubber }\end{array}$ & $\begin{array}{l}3,33 \\
3,33 \\
3,34 \\
\end{array}$ & 10 & 322 & 401 \\
\hline 8 & $\begin{array}{l}\mathrm{Zn} \text { salt of the NPA } \\
\text { Lliquid rubber }\end{array}$ & $\begin{array}{l}5 \\
5\end{array}$ & 10 & 123 & 192 \\
\hline 9 & $\begin{array}{l}\text { Zn salt of the NPA } \\
\text { Nitro compound } \\
\text { Liquid rubber }\end{array}$ & $\begin{array}{l}3,33 \\
3,33 \\
3,34\end{array}$ & 7 & 241 & 302 \\
\hline 10 & $\begin{array}{l}\mathrm{Zn} \text { salt of the NPA } \\
\text { Nitro compound } \\
\text { Liquid rubber }\end{array}$ & $\begin{array}{l}3,3,3 \\
3,3,3 \\
3,3,4 \\
\end{array}$ & 10 & 263 & 326 \\
\hline 11 & $\begin{array}{l}\text { Mg salt of the NPA } \\
\text { Liquid rubber }\end{array}$ & $\begin{array}{l}5 \\
5\end{array}$ & 10 & 123 & 192 \\
\hline 12 & $\begin{array}{l}\mathrm{Mg} \text { salt of the NPA } \\
\text { Nitro compound } \\
\text { Liquid rubber }\end{array}$ & $\begin{array}{l}3,33 \\
3,33 \\
3,34 \\
\end{array}$ & 7 & 234 & 287 \\
\hline 13 & $\begin{array}{l}\mathrm{Mg} \text { salt of the NPA } \\
\text { Nitro compound } \\
\text { Liquid rubber }\end{array}$ & $\begin{array}{l}3,33 \\
3,33 \\
3,34 \\
\end{array}$ & 10 & 297 & 353 \\
\hline 14 & $\begin{array}{l}\text { Ba salt of the NPA } \\
\text { Nitro compound } \\
\text { Liquid rubber }\end{array}$ & $\begin{array}{l}3,33 \\
3,33 \\
3,34 \\
\end{array}$ & 7 & 243 & 307 \\
\hline 15 & $\begin{array}{l}\text { Ba salt of the NPA } \\
\text { Nitro compound } \\
\text { Liquid rubber }\end{array}$ & $\begin{array}{l}3,33 \\
3,33 \\
3,34 \\
\end{array}$ & 10 & 289 & 346 \\
\hline
\end{tabular}

The dependence graph of the trial results of composition type conservation liquids on the concentration of the inhibitor is shown below: 


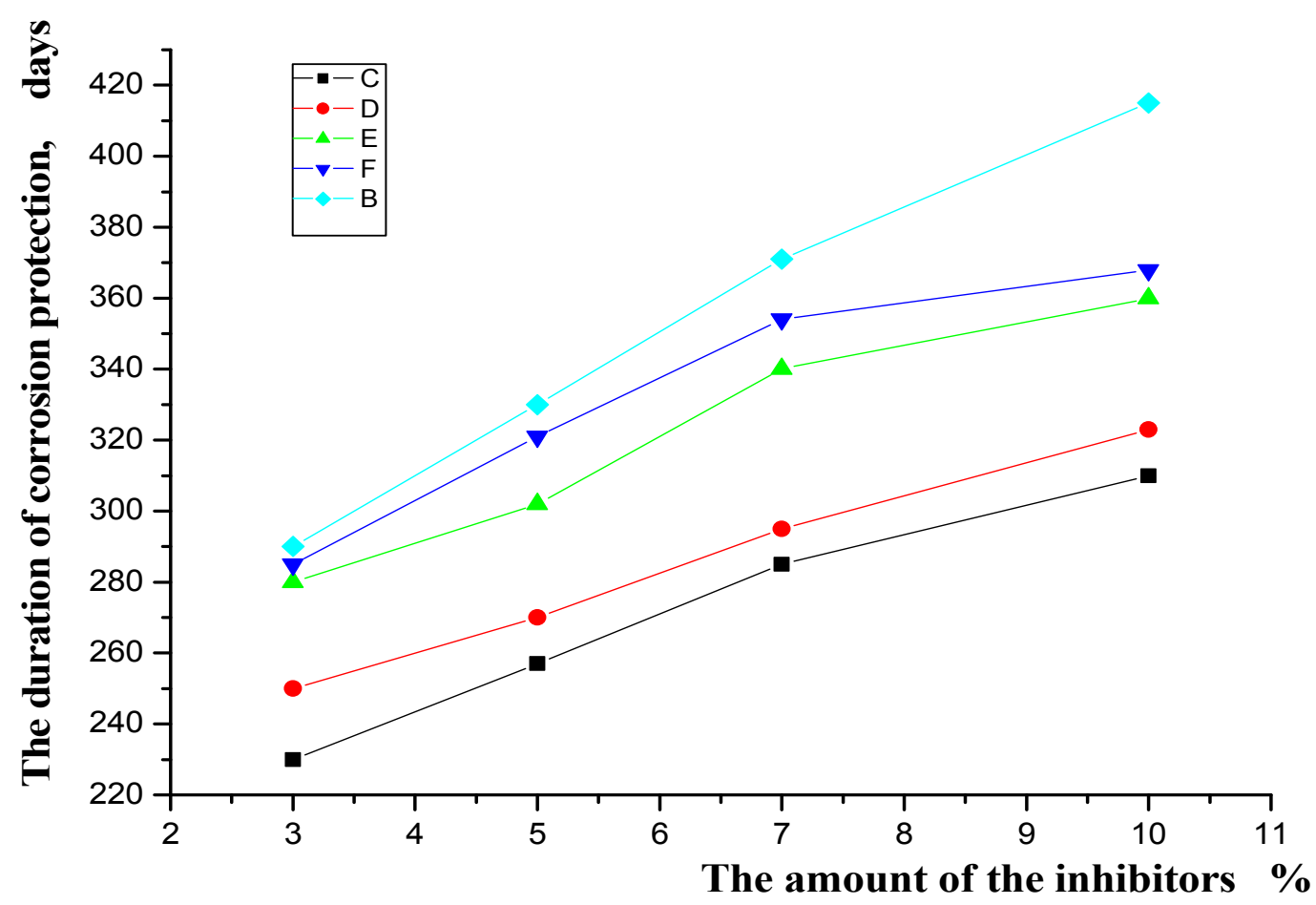

Fig. 4 - The graphical illustration of the trial results of the metal salts of NPA as composition type conservation liquids.

B - T-30 oil + Liquid rubber + Co salt of the NPA+ Nitro compound $-10 \%$

F - T-30 oil + Liquid rubber $+\mathrm{Ni}$ salt of the NPA+ Nitro compound $-10 \%$

E - T-30 oil + Liquid rubber + Zn salt of the NPA+ Nitro compound $-10 \%$

D - T-30 oil + Liquid rubber $+\mathrm{Mg}$ salt of the NPA+ Nitro compound $-10 \%$

C - T-30 oil + Liquid rubber + Ba salt of the

NPA+ Nitro compound $-10 \%$

As it is clear from the figure, the highest result was obtained from the conservation liquid which is synthesized by the composition of Co salt of the NPA (curve B). The long lasting influence of the aggressive environment on the metallic surface degrades the protective layer, as a consequence, the coating loses its function at the certain level of the experience.

As a result of the experiments, it has been revealed that, the inhibitor properties of the compositions of mineral oils with these kinds of mixture of complexes are more effective than the individual compositions with the same concentration those are prepared by adding salt and nitro compounds to the mineral oils separately. It is explained that the compositions which are produced by the metal salts of natural petroleum acids and nitro compounds create synergism effect which makes them to chemisorb on the metal surface. On the other hand, these compounds are stronger ligands than the water that is why they can substitute water molecules from the surface of the metal and create strong protection layer. It can be explained by the superior ability of chemisorption on the metal surface and producing stronger coating for protection from corrosion of these complexes.

\section{CONCLUSION}

As can be seen from the table which indicates the results of the experiments, the manufactured conservative liquids may be used in order to protect the metals from corrosion for industrial purposes. The components those have been used for producing conservative liquids are cost effective and environmentally - friendly, on the other hand, they have simple manufacturing technology and rich feedstock. T-30 oil, additives which are used as inhibitors and liquid rubber which are used in the reaction medium are produced on the basis of the feedstock which have enough reserves. So, the comparative analysis of the results reveals that, the usage of the compositions of the metal salts of natural petroleum acids with nitro compounds as inhibitors 
have a practical importance for producing more effective conservative liquids.

It has been revealed that the conservative liquid that is produced by the composition of the synthesised inhibitor and nitro compound in the presence of liquid rubber has a great protection against corrosion than their individual usages, meets the requirements and has a great practical importance.

Acknowledgment: The authors are grateful for financial support of Research Institute of Petrochemical Processes named after Academician Yu.G.Mamedaliyev, Baku, Azerbaijan.

\section{REFERENCES}

1. I.L.Rozenfeld, "Corrosion Inhibitors" McGraw-Hill. New York, 1981, p. 182.

2. V.M.Abbasov. "Korroziya" Baku, 12.02.2007, p. 355.

3. V.M.Abbasov, H.M.Abd El-Lateef, L.I.Aliyeva, I.T.Ismayilov, E.E.Qasimov, J. Korean Chem. Soc., 2013, 57, 25-34.

4. P.R.Roberge, "Corrosion Engineering Principle and Practice". McGraw-Hill. New York, 2008, p. 730.

5. E.Brinksmeier, M.Garbrecht, C.Heinzel, T.Koch, J.Eckebrecht, Tribol. Transact. V. 2009, 52, 591-601.

6. C.Emregul Kaan, A. Orhan, Mater. Chem. and Phys. 2004. 83, 373-379.

7. Y.Huang, L.-J. Yang, Y.-Z. Xu, Y.-Z. Cao \& S.D. Song, The Int. J. of Corr. Proc. and Corr. Cont. 2016, 51, 566-572.

8. Mc Connel, R. Volatile, Metal Finish. 2008, 106, 23-27.
9. N. Sridhar, D. S. Dunn, A. M. Anderko, M. M. Lencka and H. U. Schutt, Corr. J., 2001, 57, 221-235.

10. V.M.Abbasov, E.J.Aghazada, E.Sh.Abdullayev, J. of Advanc. in Chem., 2013, 15, 155-160.

11. D.A. Lopez, S.N. Simison, S.R. de Sanchez, Corr. Sci. 2005, 47, 735-755.

12. Y.J.Aghazada, J. of Advanc. in Chem., 2015, 12, 3940-3943.

13. T. Li, Y.Yang, K.Gao, M.Lu, Journal of Univ. of Sci. and Tech. Beijing, Mineral, Metallurgy, Mat.. 2008, 15, 702706.

14. V.S. Aliyev, S.M. Aliyev, A.Q. Azizov, F.A. Nasirov, Q.A. Mamedaliyev, T.A. Ismaylov, Avtorskoye svidetelstvo (A.s.)SSSR № 1066190, 1979.

15. F.A.Nasirov, Diss... cand.xim.nauk., Baku, IPP ANAS 1983, $202 \mathrm{p}$.

16. ASTM C 613-14: "Standard test method for constituent content of composite prepreg by Soxhlet Extraction".

17. Y. Takahashi, E. Matsubara, S. Suzuki, Y. Okamoto, T. Komatsu, H. Konishi, J. Mizuki and Y. Waseda, Mater. Trans., 2005, 46, 637-642.

18. A. R. Lennie, S. A. T. Redfern, P. E. Champness, C. P. Stoddart, P. F. Schofield and D. J. Vaughan. Amer. Mineral., 1997, 82, 302-309.

19. J. Chastain, in: R.C. King Jr. (Ed.), Handbook of X-ray Photoelectron Spectroscopy, Physical Electronics, Inc., 1995.

20. B.N.Tarasevich. IK-spektry osnovnyh organicheskih soedineniy.Spravochnye materialy [Infrared spectra of main organic compounds. Reference material], Moscow, 2012.

21. A.S. Fouda, H.A. Mostafa, F. El-Taib, G.Y. Elewady. Corr. Sci., 2005, 47, 1988-2004.

22. A. Popova, E. Sokolova, S. Raicheva and M. Christov. Corr. Sci., 2003, 45, 33-58. 